\title{
Heavy Metal Residues in Soil and Accumulation in Maize at Long-Term Wastewater Irrigation Area in Tongliao, China
}

\author{
Yintao Lu, ${ }^{1}$ Hong Yao, ${ }^{1}$ Dan Shan, ${ }^{2}$ Yichen Jiang, ${ }^{3}$ Shichao Zhang, ${ }^{1}$ and Jun Yang ${ }^{4}$ \\ ${ }^{1}$ School of Civil Engineering, Beijing Jiaotong University, Beijing 100044, China \\ ${ }^{2}$ Sino-Japan Friendship Centre for Environmental Protection, Beijing 100029, China \\ ${ }^{3}$ College of Environmental Sciences and Engineering, Peking University, Beijing 100871, China \\ ${ }^{4}$ School of Environmental and Municipal Engineering, Lanzhou Jiaotong University, Lanzhou, Gansu 730070, China
}

Correspondence should be addressed to Hong Yao; yaohongts@163.com

Received 18 September 2014; Accepted 9 December 2014

Academic Editor: Jun Wu

Copyright (C) 2015 Yintao Lu et al. This is an open access article distributed under the Creative Commons Attribution License, which permits unrestricted use, distribution, and reproduction in any medium, provided the original work is properly cited.

\begin{abstract}
Soil and plant samples were collected from Tongliao, China, during the maize growth cycle between May and October 2010. Heavy metals, such as $\mathrm{Cr}, \mathrm{Pb}, \mathrm{Ni}$, and $\mathrm{Zn}$, were analyzed. The concentrations of $\mathrm{Cr}, \mathrm{Pb}, \mathrm{Ni}$, and $\mathrm{Zn}$ in the wastewater-irrigated area were higher than those in the topsoil from the groundwater-irrigated area. The concentrations of metals in the maize increased as follows: $\mathrm{Pb}<\mathrm{Ni}<\mathrm{Zn}<\mathrm{Cr}$. In addition, $\mathrm{Cr}, \mathrm{Pb}$, and $\mathrm{Ni}$ mainly accumulated in the maize roots, and $\mathrm{Zn}$ mainly accumulated in the maize fruit. The results of translocation factors (TF) and bioconcentration factors (BCF) of maize for heavy metals revealed that maize is an excluder plant and a potential accumulator plant and can serve as an ideal slope remediation plant. In addition, the increasing heavy metal contents in soils that have been polluted by wastewater irrigation must result in the accumulation of $\mathrm{Cr}, \mathrm{Pb}, \mathrm{Ni}$, and $\mathrm{Zn}$ in maize. Thus, the pollution level can be decreased by harvesting and disposing of and recovering the plant material.
\end{abstract}

\section{Introduction}

Industrial and municipal wastewaters are increasingly being used as valuable resources for urban and periurban agriculture irrigation because of their availability, which partially solves the problem of effluent disposal $[1,2]$. The concentrations of heavy metals in sewage effluents are usually low, but long-term use of these wastewaters on agricultural lands often results in the buildup of elevated levels of metals in soils [3]. Because most plant roots are located in the soil, they can play important roles in metal removal via filtration, adsorption, and cation exchange, as well as through plantinduced chemical changes in the rhizosphere $[4,5]$. Cabbage, Amaranthus, spinach, radish, lady's finger, and forage grasses grown in sewage sludge amended soils had higher $\mathrm{Cd}$, $\mathrm{Cr}, \mathrm{Co}, \mathrm{Cu}, \mathrm{Pb}, \mathrm{Ni}$, and $\mathrm{Zn}$ concentrations compared to those grown in unamended soils [6]. Trace heavy metals are essential nutrients that become harmful and toxic when their concentrations exceed recommended standards [7]. Therefore, long-term irrigation using industrial/municipal wastewater results in the buildup of heavy metals in soils, which can restrict soil function, result in toxicity to plants, and contaminate the food chain by affecting food quality and safety [8].

Heavy metals often coexist in soil and plant systems. The distributions of heavy metals in the soil and their availability to plants are regulated by several factors, including soil characteristics, plant species, fertilization and irrigation characteristics, and the interrelationships between these factors. The composition and conditions of the soil are important factors that affect $\mathrm{Cr}$ mobility $[9,10]$. In addition, the environmental conditions in the rhizosphere may provide information regarding the potential impacts of plant roots on Cr mobility [11]. Plant factors include physical processes (such as root intrusion); water and ion fluxes and their relationships with membrane transport kinetics, ion interactions, and the metabolic fate of the absorbed ions; and the ability of plants to adapt metabolically to changing metal stresses in the environment [12]. Some studies have shown the spatial distribution of heavy metals in wastewater irrigation 
areas $[13,14]$. In addition, several studies have emphasized the risks of heavy metal accumulation in topsoils irrigated with wastewater [15-19]. Furthermore, several studies have demonstrated that wastewater-irrigated plants may absorb and accumulate heavy metals at concentrations that are greater than the maximum permissible limits, which can result in serious public health problems [20-22]. Although Shah et al. [7] studied the accumulation of heavy metals in different plants, few studies have been published regarding the accumulation of heavy metal in different plant organs. In addition, some heavy metals are not toxic to plants and serve as essential nutrients, such as $\mathrm{Zn}$ and $\mathrm{Cu}$ [23]. These nutrients are often deficient in calcareous soils and must be supplied [24]. Therefore, it is important to assess heavy metal pollutant concentrations in crops to ensure safe food production and prevent environmental and public health risks.

Maize (Zea mays L.) is an edible flowering plant in the Gramineae family and is a warm-season crop that is easily grown during the spring and summer. Additionally, maize serves as the main food source for humans and animals around the world. Inner Mongolia is a large agriculture province that serves as an important maize production area for China. The wastewater irrigation area considered in this study mainly includes Tongliao City and Hohhot City. Wastewater irrigation has occurred in Tongliao since the 1970s for more than 30 years over an area of $750 \mathrm{~h} \mathrm{~m}^{3}$. Numerous studies have reported the accumulation of different heavy metals in plant tissues $[25,26]$. However, limited information is available regarding the heavy metal concentrations and long-term effects of wastewater irrigation in maize production systems. In this study, fertilizer and longterm wastewater application were conducted with maize fruit production in an arid area in Tongliao, China. The overall objectives of this study were to (1) investigate the temporal changes of heavy metals during the maize growth cycle, (2) investigate the heavy metal accumulation in maize organs and determine the accumulation and excluder abilities of maize for four metals, and (3) determine the changes in the heavy metal concentrations in wastewater- and groundwaterirrigated area.

\section{Materials and Methods}

2.1. Description of the Study Area. The study area is located in Tongliao, which is in the northeastern region of China $\left(43^{\circ} 38^{\prime} 11^{\prime \prime}-45^{\circ} 50^{\prime} 13^{\prime \prime} \mathrm{N} ; 119^{\circ} 13^{\prime} 28^{\prime \prime}-122^{\circ} 31^{\prime} 52^{\prime \prime} \mathrm{E}\right)$. This area is located in the semiarid grassland area in the North Temperate Zone and has a continental monsoon climate with a mean annual temperature of $5^{\circ} \mathrm{C}$. In addition, this area is arid with an annual water deficit of $350 \mathrm{~mm}$ because the potential evaporation exceeds precipitation. The dry season is from November to April, and the wet season is from June to September. The dominant vegetation species is maize, and the wastewater treatment plant in Tongliao City treats approximately $70,000 \mathrm{~m}^{3} / \mathrm{d}$ of sewage. Most of the treated effluent flows into the Xiliao River, and some of the effluent is used for irrigating suburban farms. Farmers generally used a primary sedimentation pond to treat effluent without any

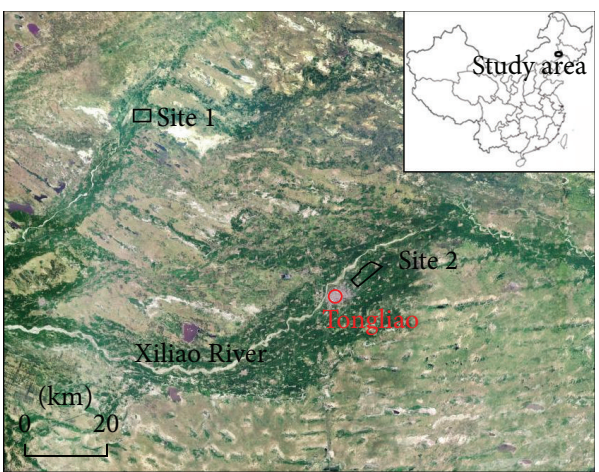

FIGURE 1: Location of the study site. Site 1 shows the maize growth area that was used to study the temporal changes of the heavy metal concentrations in soils and maize organs. Site 2 is the control area of wastewater and/or groundwater irrigation and was used to study the impacts of wastewater irrigation on the soil.

biological treatment from 1985 to 2007. After 2007, farmers began to use a secondary sedimentation pond after the effluent was subjected to anaerobic-anoxic-oxic processes at wastewater treatment plants. No detailed data are available regarding the use of wastewater for irrigation from 1985 to 2007. However, the main quality parameter levels of TSW (the treated sewage) and groundwater were just below the USW (the untreated sewage). All parameters were within the limits of the GB20922-2007 requirements and corresponded with agricultural water quality standards. The $\mathrm{COD}, \mathrm{BOD}_{5}, \mathrm{TN}$, and TP concentrations in the irrigation wastewater from 1985 were greater in the groundwater. Thus, long-term wastewater irrigation can enhance these concentrations in the soil.

2.2. Sampling of Soil and Maize. The field soil samples were collected in Tongliao, China, during the maize growth cycles from May to October 2010 (Figure 1). Two sites were considered in the study area. Site 1 is a demonstration area of maize growth with two fertilizer applications and four wastewater irrigations. Site 2 is the control area for wastewater and/or groundwater irrigation and was used to study the impacts of wastewater irrigation on the soil. At site 1,18 soils (collected in the topsoil at depths of $0-20 \mathrm{~cm}$ ) and maize (including root, stem, leaves, and fruit) samples were collected. The maize samples were collected in triplicate from the field when the maize was mature. The samples were placed in clean plastic bags before being transported to the laboratory for analysis. At site 2, 42 soil samples were collected around the irrigation drain and in the farming area at depths of 0 $20 \mathrm{~cm}$. Of these samples, 20 were collected in the wastewaterirrigated area and 20 were collected in the groundwaterirrigated area. The other 2 sampling sites were collected at nine different depths from the top of the soil, $0-20 \mathrm{~cm}, 20$ $40 \mathrm{~cm}, 40-60 \mathrm{~cm}, 60-80 \mathrm{~cm}, 80-100 \mathrm{~cm}, 100-110 \mathrm{~cm}, 110-$ $130 \mathrm{~cm}, 130-150 \mathrm{~cm}$, and $150-170 \mathrm{~cm}$. These samples were collected from the wastewater-irrigated and groundwaterirrigated areas, respectively. The soil samples were placed in sealed polyethylene plastic bag. After extraction, the soil and plant samples were preserved in ice-packed coolers before 
transferring them to the laboratory and storing at $4^{\circ} \mathrm{C}$ in a cold room until analysis.

2.3. Sample Treatment and Analysis. Before treatment, the soil samples were passed through a 100 -mesh sieve. Soil samples were digested in aqua regia at $160^{\circ} \mathrm{C}$, as previously described [27]. The maize samples were cleaned with deionized water and the leaves, roots, stems, and fruit were separated. After oven-drying the samples at $70^{\circ} \mathrm{C}$ until a constant weight was achieved, the samples were ground to powder. All samples were passed through a 40-mesh nylon plastic sieve after drying. Next, the subsamples were digested in $5 \mathrm{~mL}$ of concentrated Analar $\mathrm{HNO}_{3}$ at $160^{\circ} \mathrm{C}$ [20]. The $\mathrm{Cr}$ and $\mathrm{Pb}$ concentrations were determined using ICP-OES (Perkin-Elmer OPTIMA-2000, USA), and the Ni and Zn concentrations were measured using ICP-MS (Agilent 7500a). The glassware used for measuring the metal concentrations was soaked in $20 \% \mathrm{HNO}_{3}$ overnight. Blank samples were included with every 12 samples to check for contamination. One reference soil from the Chinese National Standard Soil Bank (GBW07402 (GSS-2)) was used with each of the 12 samples to validate the accuracy of the metal analysis. All of the analyses were carried out in triplicate, and the standard deviations were within $\pm 5 \%$ of the mean.

2.4. Data Processing and Statistical Analysis. In this study, the translocation factor (TF) and the bioconcentration factor (BCF) were calculated using the ratio of the heavy metal concentrations in the roots and shoots $\left[\mathrm{TF}=C_{\text {shoot }} / C_{\text {root }}\right]$ and the ratio of the heavy metal concentrations in the soils and shoots $\left[\mathrm{BCF}=C_{\text {shoot }} / C_{\text {soil }}\right]$, respectively [28-30]. To determine the heavy metal concentrations in the shoots, the values found for the leaves and stems were multiplied by the total biomass of each organ and were added to obtain the total mass of the heavy metals in the aerial organs. Next, this result was divided by the total mass of the aerial organs (stems plus leaves) [26]. The heavy metal data were subjected to a one-way analysis of variance (ANOVA) using the Statistical Package for Social Science (IBM SPSS Statistics 19) and the means were separated by using Duncan's multiple range test (DMRT) as described by Steel and Torrie [31] (at $P<0.05)$. In addition, Pearson's correlation coefficient was used to determine the relationships between the heavy metal concentrations in the soils and plants at $P<0.05$.

\section{Results and Discussion}

3.1. Temporal Characteristics of the Soil Metal Concentrations during the Maize Growth Cycle. Figure 2 shows the temporal changes in the heavy metal concentrations during the maize growth cycle (from May to October) at site 1 . In addition, the changes in the metal concentrations showed a strong temporal character. The highest mean concentration of $\mathrm{Cr}$ in the soil was $12.05 \mathrm{mg} / \mathrm{kg}$, which occurred in September, and the lowest mean concentration was $11.12 \mathrm{mg} / \mathrm{kg}$, which occurred in June. Soil Cr plays important roles in the metabolism of cholesterol, fat, and glucose. Banks et al. indicated that the plant uptake of $\mathrm{Cr}$ accounted for less than $1 \%$ of the $\mathrm{Cr}$ that was removed from the soil [10]. Therefore, the $\mathrm{Cr}$ concentration in the soil mainly showed an accumulation effect due to the fertilizer and wastewater inputs. The highest mean $\mathrm{Pb}$ concentration in the soil was $12.39 \mathrm{mg} / \mathrm{kg}$, which occurred in September, and the lowest mean concentration was $10.89 \mathrm{mg} / \mathrm{kg}$, which occurred in May. Although the $\mathrm{Pb}$ contents in plants depend on different environmental factors $[26,32]$, the $\mathrm{Pb}$ contents of plants grown in uncontaminated soils are usually between 0.1 and $10 \mathrm{mg} / \mathrm{kg}$, with an average of $2 \mathrm{mg} / \mathrm{kg}$ [33]. These results indicated that the soil was contaminated with $\mathrm{Pb}$ due to agricultural activities. The highest mean Ni concentration in the soil was $6.74 \mathrm{mg} / \mathrm{kg}$ and occurred during September, and the lowest concentration was $5.9 \mathrm{mg} / \mathrm{kg}$ and occurred during May. In small quantities, $\mathrm{Ni}$ is necessary for regulating lipid contents in tissues and for forming red blood cells. Various factors influence this result. First, the overall uptake of Ni by plants depends on the $\mathrm{Ni}^{2+}$ concentration, plant metabolism, soil or solution acidity, presence of other metals, and organic matter composition [34]. In addition, Ni may compete with other essential metal ions during absorption by roots [35]. The changes in the $\mathrm{Cr}$, $\mathrm{Pb}$, and $\mathrm{Ni}$ concentrations in the soil increased from May to September and decreased in October. In this area, the soils were fertilized regularly and irrigated with wastewater to promote maize growth from May to September. However, concerns exist regarding the accumulation of heavy metals in soils after wastewater irrigation and fertilization, which could result in their transfer to maize roots and maize fruit. The concentrations of heavy metals that result from fertilization and wastewater are higher than the intake of maize, which results in the buildup of heavy metal residues in the soil. Fendorf et al. determined that waste $\mathrm{Cr}$ and $\mathrm{Pb}$ are considered to have low bioaccessibility soon after they enter the soil [36].

The highest mean $\mathrm{Zn}$ concentration in the soil was $12.13 \mathrm{mg} / \mathrm{kg}$, which occurred in October, and the lowest mean concentration was $8.47 \mathrm{mg} / \mathrm{kg}$, which is in June. The $\mathrm{Zn}$ concentration in the soil was low and hardly changed. Outridge and Noller indicated that $\mathrm{Zn}$ is an essential element for all plants and that the mean concentration of $\mathrm{Zn}$ in normal plants (aboveground tissues) is $66 \mathrm{mg} / \mathrm{kg}$ [37]. However, $\mathrm{Zn}$ deficiencies are common in calcareous soils. The Chernozems and Kastanozems soil groups have a high $\mathrm{pH}$ and $\mathrm{CaCO}_{3}$ content, which indicates that they are $\mathrm{Mn}$ and $\mathrm{Zn}$ deficient [38]. The calcareous soils were covered by topsoil and were mainly composed of $\mathrm{CaCO}_{3}$. In addition, Jiménez et al. indicated that the $\mathrm{Zn}$ and $\mathrm{Cu}$ concentrations in the plants were closely related to the soil $\mathrm{CaCO}_{3}$ contents and electrical conductivity [39].

\subsection{Accumulation and Correlation of Heavy Metal Concen-} trations in Maize Organs. The concentrations of $\mathrm{Cr}, \mathrm{Pb}, \mathrm{Ni}$, and $\mathrm{Zn}$ in maize roots, stems, leaves, and fruits are presented in Figure 3. Each heavy metal exhibited a different trend in the different maize organs. The highest concentrations of $\mathrm{Cr}$, $\mathrm{Pb}$, and $\mathrm{Ni}$ were observed in the maize roots, with mean concentrations of $105.21,5.12$, and $6.56 \mathrm{mg} / \mathrm{kg}$, respectively. The lowest values of the four maize bodies for $\mathrm{Cr}, \mathrm{Pb}$, and $\mathrm{Zn}$ occurred in the fruit, with mean values of $0.23,0.49$, and $0.18 \mathrm{mg} / \mathrm{kg}$, respectively. These results indicated that large 


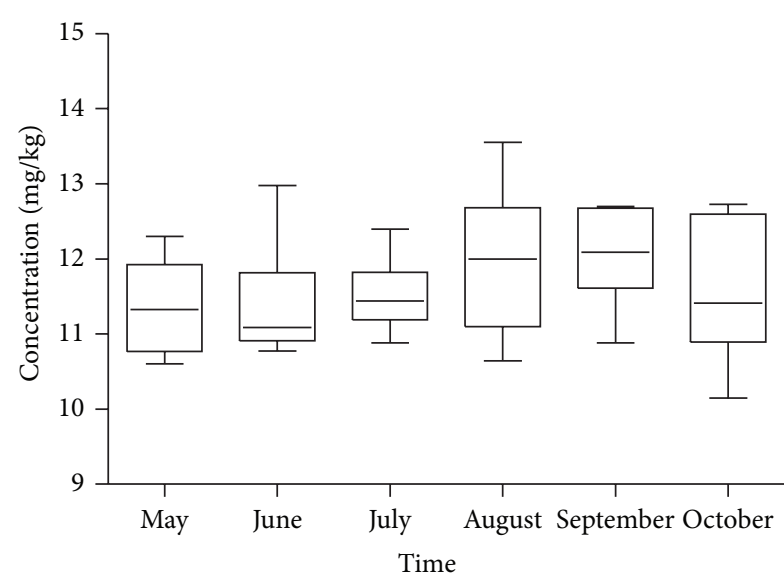

(a)

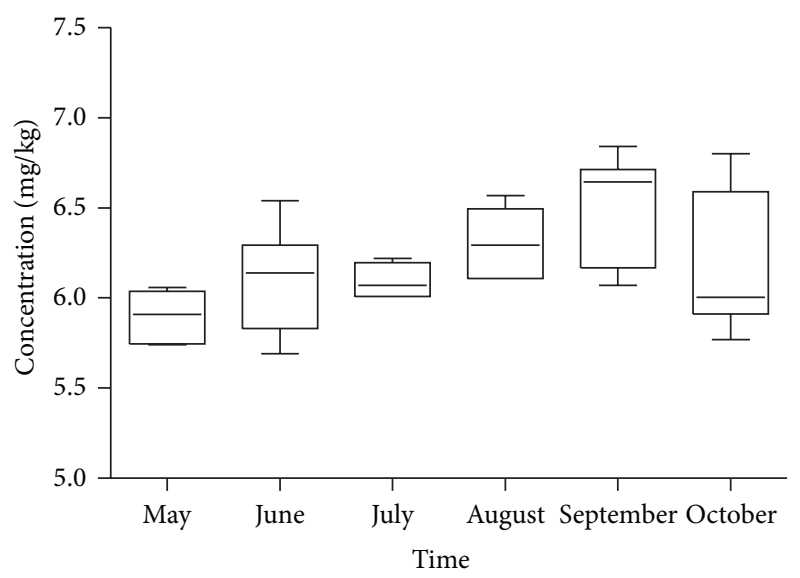

(c)

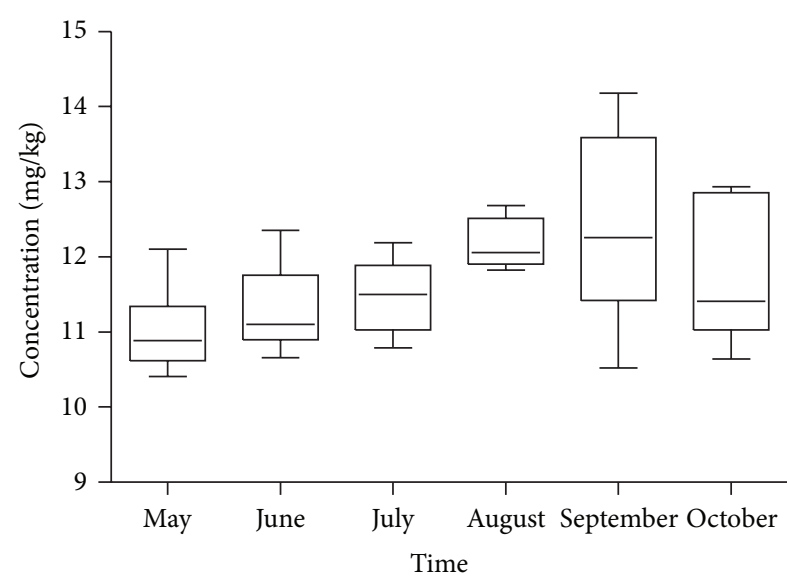

(b)

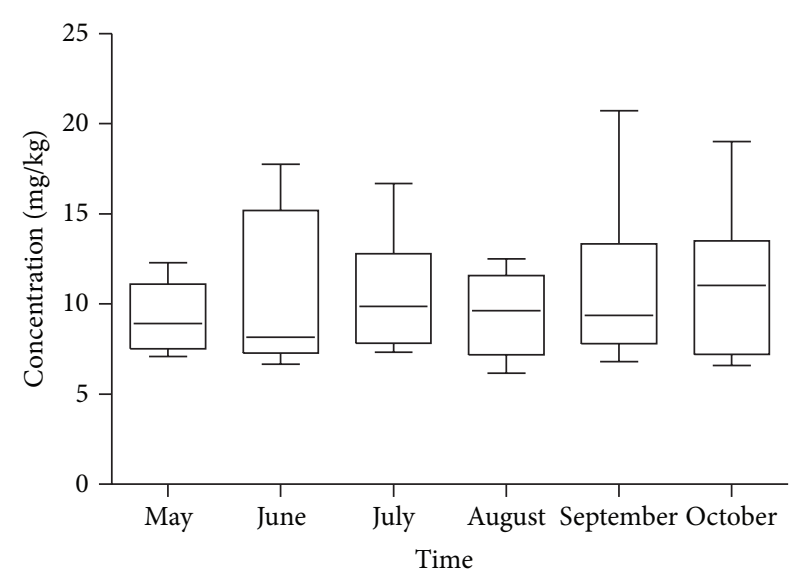

(d)

Figure 2: Temporal variations of the soil heavy metal concentrations at site 1. (a) Changes in the $\mathrm{Cr}$ concentration; (b) changes in the $\mathrm{Pb}$ concentration; (c) changes in the Ni concentration; and (d) changes in the Zn concentration.

amounts of $\mathrm{Cr}, \mathrm{Pb}$, and $\mathrm{Ni}$ were maintained in the maize roots, despite the relatively low concentrations of these metals in the soil, especially $\mathrm{Cr}$. In addition, $\mathrm{Cr}$ was absorbed well by the maize roots. However, contrasting results have shown that the $\mathrm{Pb}$ concentrations were lower in the roots than in the shoots of hot pepper and celery plants [40]. This difference potentially resulted from a change in the transfer direction of $\mathrm{Pb}$. For example, when the direction is from down to up, $\mathrm{Pb}$ is prone to accumulate in the maize roots. However, when the direction is from up to down, $\mathrm{Pb}$ is prone to accumulate in the shoots. The changes of the $\mathrm{Zn}$ concentrations were different for the other three metals. The highest $\mathrm{Zn}$ concentrations occurred in the maize fruit, with a mean value of $6.92 \mathrm{mg} / \mathrm{kg}$. The lowest $\mathrm{Zn}$ concentrations occurred in the maize stem, with a mean value of $2.11 \mathrm{mg} / \mathrm{kg}$.

Generally, the metal concentrations in maize increased as follows: $\mathrm{Pb}<\mathrm{Ni}<\mathrm{Zn}<\mathrm{Cr}$. The mean $\mathrm{Cr}, \mathrm{Pb}, \mathrm{Ni}$, and $\mathrm{Zn}$ concentrations in the maize organs decreased in the following orders: root $>$ leaves $>$ stem $>$ fruit, root $>$ leaves $>$ stem $>$ fruit, root $>$ stem $>$ leaves $>$ fruit, and fruit $>$ root $>$ leaves $>$ stem, respectively. The same results were shown in several recent studies. For example, Thapliyal et al. considered that the $\mathrm{Cr}$ concentration decreased in the following order roots $>$ leaves $>$ fruit in green chili under untreated wastewater irrigation [41]. In addition, the different plant parts were reported to accumulate different amounts of heavy metals, with the greatest contents occurring in roots and leaves and the smallest contents occurring in flower buds and fruit [42].

Rascio and Navari-Izzo reported that two types of higher plants can tolerate high heavy metal concentrations in the soil [43], accumulator plants and excluder plants. To determine if a plant is a metal accumulator or an excluder, the BCF and TF must be considered $[44,45]$. Excluder plants can inhibit metal entrance into the plant or restrict root-to-shoot translocation (featuring $\mathrm{TF}<1$ ). Accumulator plants can actively take up heavy metals from the soil and translocate them from the root to the shoots, resulting in accumulation in their aboveground organs, featuring $\mathrm{BCF} \geq 0.2$ and $\mathrm{TF}>1[44,45]$. Table 1 presents the TF and BCF for maize at site 1 . The TF values of the maize for $\mathrm{Cr}, \mathrm{Pb}, \mathrm{Ni}$, and $\mathrm{Zn}$ were $0.12,0.43,0.23$, and 0.64 , respectively. The $\mathrm{BCF}$ values of the maize for $\mathrm{Cr}, \mathrm{Pb}$, $\mathrm{Ni}$, and $\mathrm{Zn}$ were $1.03,0.19,0.25$, and 0.26 , respectively. Plant uptake is largely influenced by the bioavailability of metals, which is determined by both external (soil-associated) and 


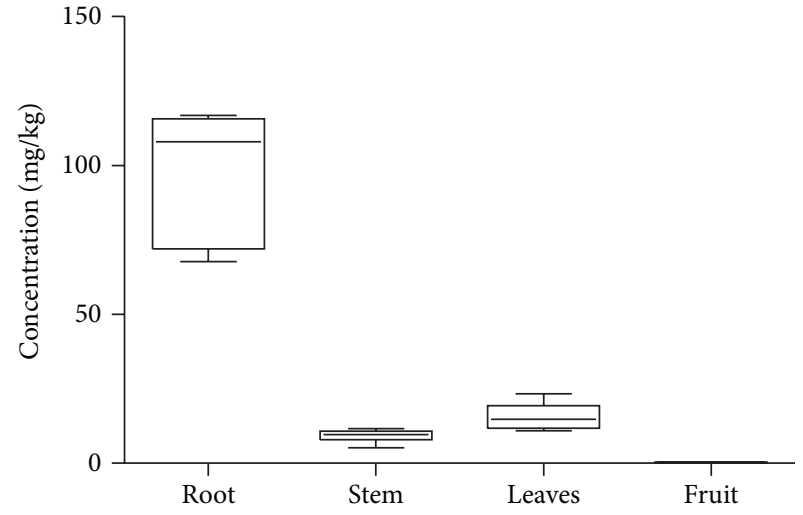

(a)

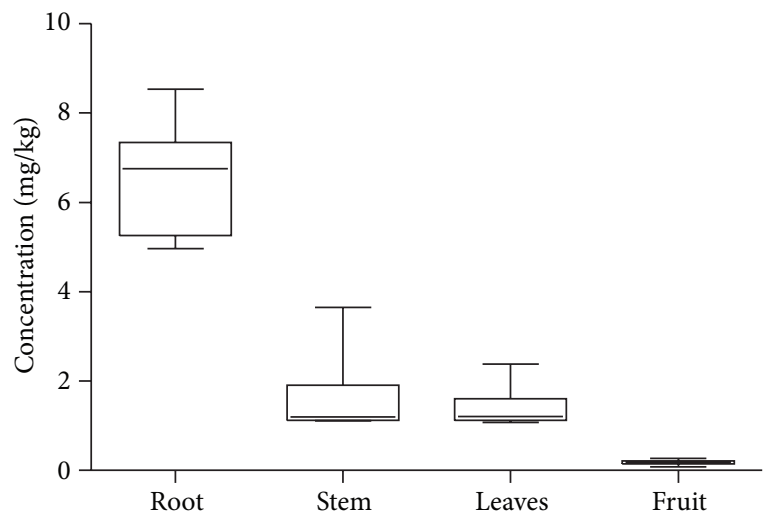

(c)

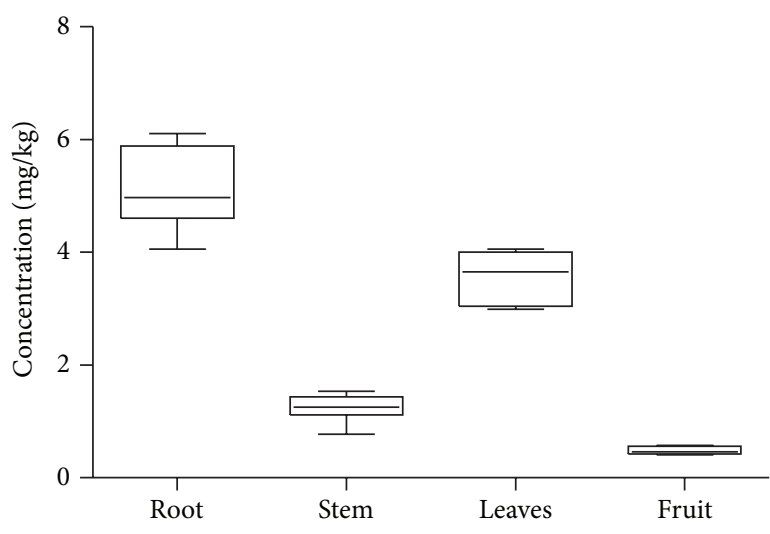

(b)

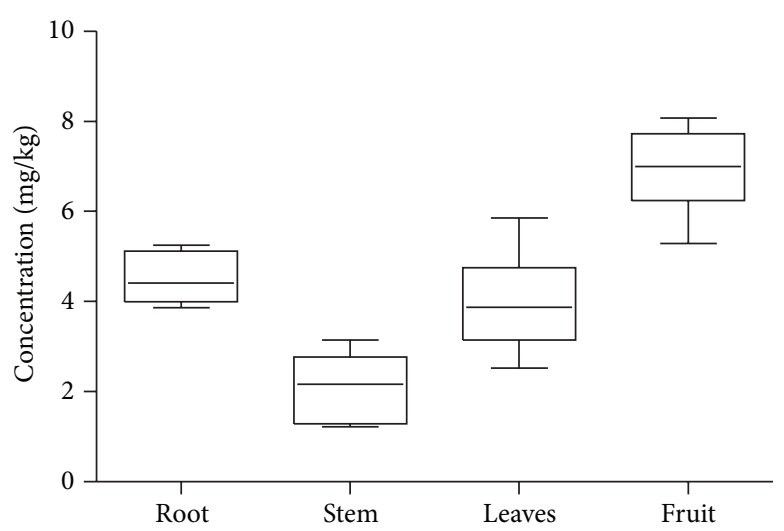

(d)

FIGURE 3: Heavy metal concentrations in the roots, stems, leaves, and fruit of maize. (a) Cr; (b) Pb; (c) Ni; (d) Zn.

TABLE 1: The accumulation of heavy metals ( $\mathrm{mg} / \mathrm{kg}$ ) in maize roots, stems, leaves, and fruits, the maize TF and BCF values, and the ANOVA results for the heavy metals concentrations at site 1 .

\begin{tabular}{lcccc}
\hline & $\mathrm{Cr}$ & $\mathrm{Pb}$ & $\mathrm{Ni}$ & $\mathrm{Zn}$ \\
\hline Root & $105.21 \pm 21.79^{\mathrm{a}}$ & $5.12 \pm 0.75^{\mathrm{a}}$ & $6.56 \pm 1.27^{\mathrm{a}}$ & $4.51 \pm 0.56^{\mathrm{a}}$ \\
Stem & $9.29 \pm 2.26^{\mathrm{bc}}$ & $1.25 \pm 0.26^{\mathrm{b}}$ & $1.61 \pm 1.00^{\mathrm{b}}$ & $2.11 \pm 0.75^{\mathrm{b}}$ \\
Leaves & $15.63 \pm 4.72^{\mathrm{b}}$ & $3.57 \pm 0.49^{\mathrm{c}}$ & $1.40 \pm 0.49^{\mathrm{b}}$ & $3.98 \pm 1.12^{\mathrm{a}}$ \\
Fruit & $0.23 \pm 0.11^{\mathrm{c}}$ & $0.49 \pm 0.07^{\mathrm{c}}$ & $0.18 \pm 0.06^{\mathrm{c}}$ & $6.92 \pm 0.97^{\mathrm{c}}$ \\
TF & 0.12 & 0.43 & 0.23 & 0.64 \\
BCF & 1.03 & 0.19 & 0.25 & 0.26 \\
\hline
\end{tabular}

Note: means followed by different letters within the same column are significantly different from each other at $P<0.05$ according to DMRT.

internal (plant-associated) factors. However, the TF (internal factor) of maize for heavy metals increased in the following order: $\mathrm{Cr}<\mathrm{Ni}<\mathrm{Pb}<\mathrm{Zn}$. In addition, the BCF (external factor) increased in the following order: $\mathrm{Pb}<\mathrm{Ni}<\mathrm{Zn}<$ $\mathrm{Cr}$. These increases are consistent with the results shown in Figure 3. The BCF and TF values of the maize for $\mathrm{Pb}, \mathrm{Ni}$, and $\mathrm{Zn}$ were all less than 1 , which indicated lower $\mathrm{Pb}, \mathrm{Ni}$, and $\mathrm{Zn}$ concentrations in their root and aerial organs. Maize was an excluder plant for $\mathrm{Pb}, \mathrm{Ni}$, and $\mathrm{Zn}$ because it hindered the entrance of metal. The BCF values of maize for $\mathrm{Cr}, \mathrm{Ni}$, and $\mathrm{Zn}$ were $\geq 0.2$. Thus, maize is a potential accumulator plant and can serve as an ideal slope remediation plant.
3.3. Comparison of Heavy Metal Concentrations in the Soil Wastewater-Irrigated and Groundwater-Irrigated Areas. The heavy metal concentrations in different irrigation areas are presented in Table 2. The metal concentrations in the wastewater-irrigated area were greater than in the groundwater-irrigated area, and the range and standard deviation were considerably greater in the wastewater-irrigated area, especially $\mathrm{Zn}$. The $\mathrm{Cr}, \mathrm{Pb}, \mathrm{Ni}$, and $\mathrm{Zn}$ concentrations in the wastewater-irrigated area were $23.17-39.54,3.49-$ $21.48,5.64-18.60$, and $25.48-297.50 \mathrm{mg} / \mathrm{kg}$, respectively. The $\mathrm{Cr}, \mathrm{Pb}, \mathrm{Ni}$, and $\mathrm{Zn}$ concentrations in the groundwaterirrigated area were $22.93-37.75,3.97-21.14,8.34-18.00$, and 


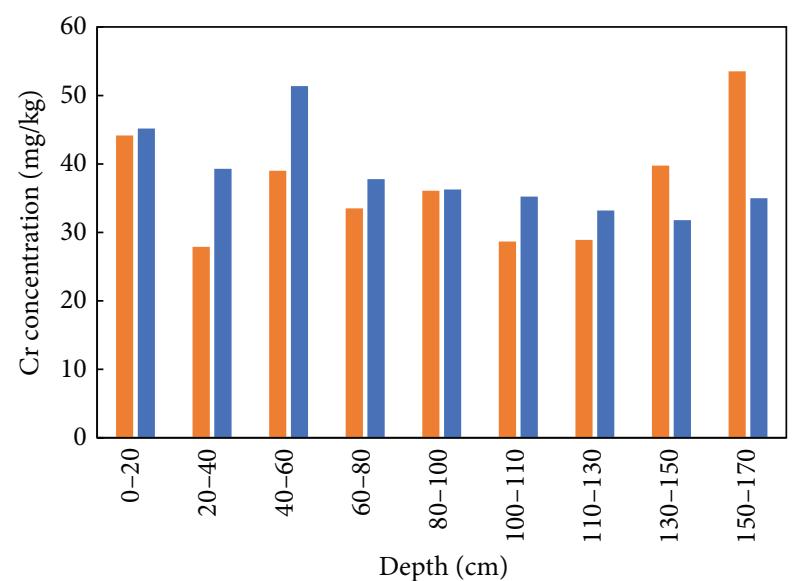

- Groundwater-irrigated area

- Wastewater-irrigated area

(a)

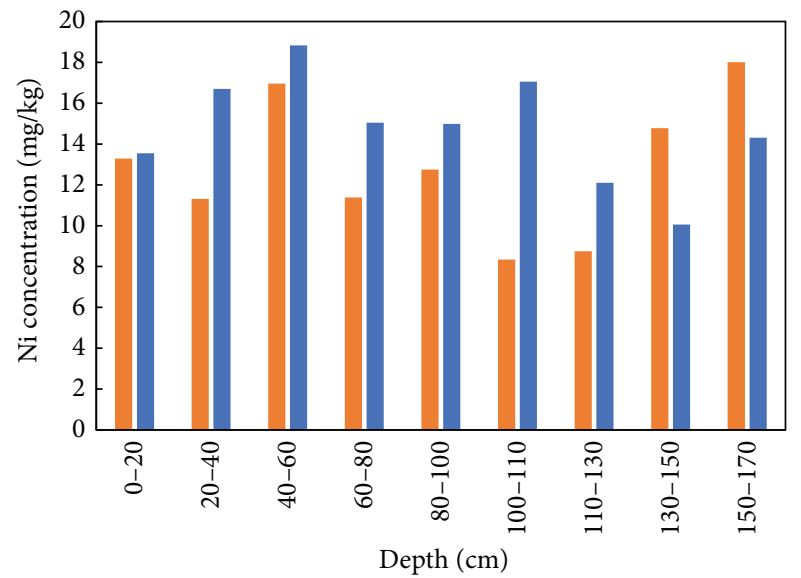

- Groundwater-irrigated area

- Wastewater-irrigated area

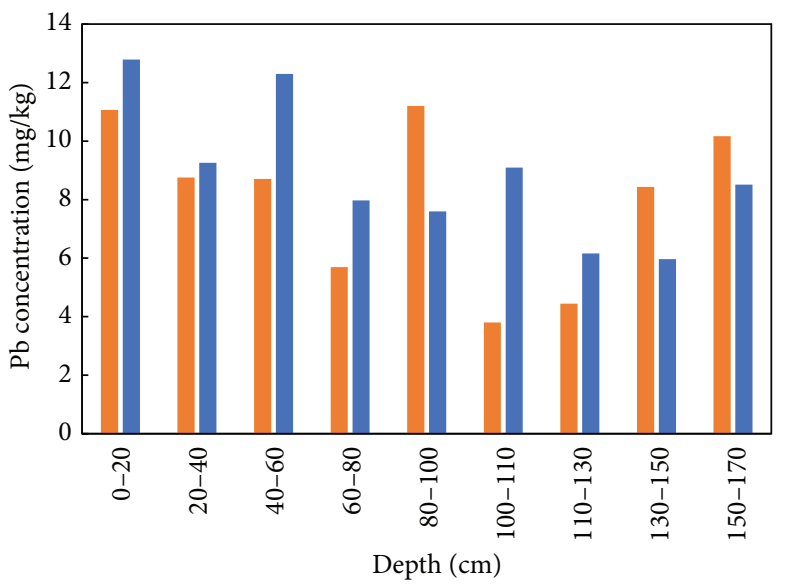

- Groundwater-irrigated area

- Wastewater-irrigated area

(b)

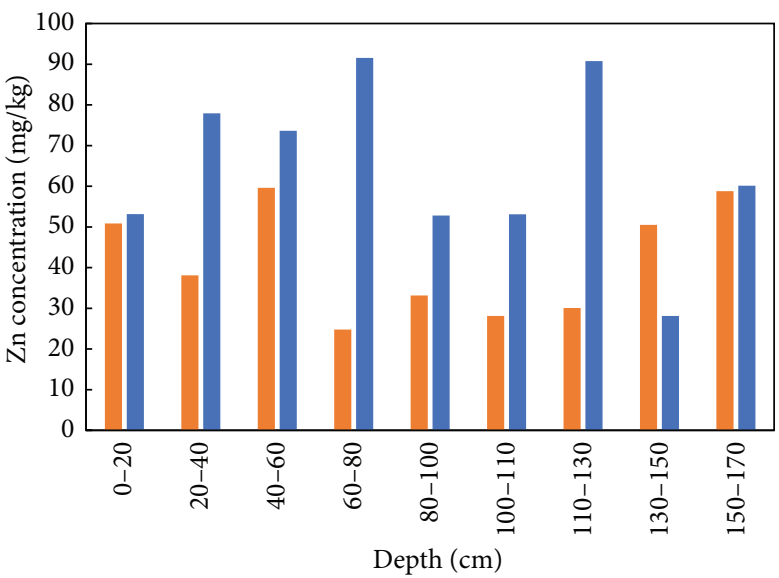

- Groundwater-irrigated area

- Wastewater-irrigated area

(d)

Figure 4: The vertical profiles of heavy metals in soils from wastewater-irrigated and groundwater-irrigated areas. (a) $\mathrm{Cr}$; (b) $\mathrm{Pb}$; (c) $\mathrm{Ni}$; (d) $\mathrm{Zn}$.

TABLE 2: Metal concentrations ( $\mathrm{mg} / \mathrm{kg}$ ) in the soil samples collected from wastewater-irrigated and groundwater-irrigated areas $(n=20)$.

\begin{tabular}{ccc}
\hline & Wastewater-irrigated area & Groundwater-irrigated area \\
\hline $\mathrm{Cr}$ & $29.86 \pm 4.46^{\mathrm{a}}$ & $28.77 \pm 3.67^{\mathrm{a}}$ \\
$\mathrm{Pb}$ & $7.39 \pm 4.21^{\mathrm{b}}$ & $7.15 \pm 4.84^{\mathrm{b}}$ \\
$\mathrm{Ni}$ & $13.30 \pm 3.76^{\mathrm{ab}}$ & $12.84 \pm 3.34^{\mathrm{b}}$ \\
$\mathrm{Zn}$ & $86.00 \pm 66.90^{\mathrm{c}}$ & $62.54 \pm 26.74^{\mathrm{c}}$ \\
\hline
\end{tabular}

Note: means followed by different letters within a column are significantly different from each other at $P<0.05$ according to DMRT.

$23.78-111.45 \mathrm{mg} / \mathrm{kg}$, respectively. However, the average $\mathrm{Cr}, \mathrm{Pb}$, $\mathrm{Ni}$, and $\mathrm{Zn}$ concentrations in the wastewater- and groundwater-irrigated areas were lower than the upper threshold of the National Standard for Soil Environment Quality $(90 \mathrm{mg} / \mathrm{kg}$ for $\mathrm{Cr}, 35 \mathrm{mg} / \mathrm{kg}$ for $\mathrm{Pb}, 40 \mathrm{mg} / \mathrm{kg}$ for $\mathrm{Ni}$, and $100 \mathrm{mg} / \mathrm{kg}$ for $\mathrm{Zn}$ ). These results correspond with the findings of Avci and Deveci, who observed that the mean $\mathrm{Cr}, \mathrm{Ni}, \mathrm{Pb}$, and $\mathrm{Zn}$ concentrations were somewhat greater in the wastewaterirrigated soil samples than in the control samples [46]. Tiwari et al. reported greater metal concentrations $(\mathrm{Fe}>\mathrm{Mn}>\mathrm{Zn}>$ $\mathrm{Cd}>\mathrm{Cu}>\mathrm{Pb}>\mathrm{Cr}$ ) in a soil that was irrigated with effluent than in a soil that was irrigated with tube well water [47].

In this study, the $\mathrm{Cr}, \mathrm{Pb}$, and $\mathrm{Ni}$ concentrations in the wastewater-irrigated area were greater than those in the groundwater-irrigated area at $0-130 \mathrm{~cm}$, and the concentrations in the wastewater-irrigated area were lower at 130$170 \mathrm{~cm}$ (Figure 4). This phenomenon depends on the irrigation conditions, soil properties, water cycles, biological processes, and so forth. The $\mathrm{Zn}$ concentrations at all soil depths in the wastewater-irrigated areas were greater than those in the groundwater-irrigated areas, except at a depth of $130-150 \mathrm{~cm}$. It is known that $\mathrm{Zn}$ ions bind strongly to soil particles, cause metal pollution when dissolved in water, and inadvertently negate the activities of microorganisms and 
macroorganisms in the soil [48]. Maize roots are distributed in the topsoil, increase the heavy metal content in the soil, and must lead to the accumulation of $\mathrm{Cr}, \mathrm{Pb}, \mathrm{Ni}$, and $\mathrm{Zn}$ in maize based on the result of the demonstration area of maize growth (site 1). However, because maize is a potential accumulator plant, it is possible to decrease pollution levels by harvesting, disposing of, and recovering the plant.

\section{Conclusions}

Heavy metal concentrations in soils depend on the management of fertilization and wastewater irrigation. Thus, the $\mathrm{Cr}, \mathrm{Pb}$, and $\mathrm{Ni}$ concentrations were greater in the soils from May to September and decreased in October. The $\mathrm{Zn}$ concentration in the soil was closely related to the soil $\mathrm{CaCO}_{3}$ concentration and the electrical conductivity. In addition, the soil $\mathrm{Zn}$ concentrations changed differently compared to the soil $\mathrm{Cr}, \mathrm{Pb}$, and $\mathrm{Ni}$ concentrations. While $\mathrm{Cr}, \mathrm{Pb}$, and $\mathrm{Ni}$ mainly accumulated in the maize roots, $\mathrm{Zn}$ mainly accumulated in the maize fruit. Because $\mathrm{TF}<1$ and $\mathrm{BCF} \geq$ 0.2 , maize was considered as both an excluder plant for $\mathrm{Pb}, \mathrm{Ni}$, and $\mathrm{Zn}$ and a potential accumulator plant. In addition, maize is an ideal slope remediation plant. The metal concentrations in the wastewater-irrigated area were greater than in the groundwater-irrigated area. Greater heavy metal contents in the soil result in the accumulation of $\mathrm{Cr}, \mathrm{Pb}, \mathrm{Ni}$, and $\mathrm{Zn}$ in the maize organs. However, because maize was a potential accumulator plant, we decreased the pollution level by harvesting, disposing of, and recovering the plant material.

\section{Conflict of Interests}

The authors declare that there is no conflict of interests regarding the publication of this paper.

\section{Acknowledgments}

This study was supported by the Fundamental Research Funds for Beijing Jiaotong University (no. C13JB00070), the National Natural Science Foundation of China (no. 41103007), and the Application and Development Fund from the Ministry of Sciences and Technology of the Inner Mongolia Autonomous Region (no. 2009058). The authors are grateful to the State Key Laboratory of Environmental Aquatic Chemistry, the Research Center for Eco-Environmental Sciences, and the Chinese Academy of Sciences for their soil sampling and analysis. The authors also thank all supporters from the Tongliao Environmental Protection Agency and all reviewers and editors for their valuable comments and suggestions during the review process.

\section{References}

[1] V. K. Mishra, A. R. Upadhyay, and B. D. Tripathi, "Bioaccumulation of heavy metals and two organochlorine pesticides (DDT and BHC) in crops irrigated with secondary treated waste water," Environmental Monitoring and Assessment, vol. 156, no. 1-4, pp. 99-107, 2009.
[2] S. Gupta, S. Satpati, S. Nayek, and D. Garai, "Effect of wastewater irrigation on vegetables in relation to bioaccumulation of heavy metals and biochemical changes," Environmental Monitoring and Assessment, vol. 165, no. 1-4, pp. 169-177, 2010.

[3] A. K. Chopra and C. Pathak, "Bioaccumulation and translocation efficiency of heavy metals in vegetables grown on longterm wastewater irrigated soil near Bindal River, Dehradun," Agricultural Research, vol. 1, no. 2, pp. 157-164, 2012.

[4] J. S. Dunbabin and K. H. Bowmer, "Potential use of constructed wetlands for treatment of industrial wastewaters containing metals," Science of the Total Environment, vol. 111, no. 2-3, pp. 151-168, 1992.

[5] D. J. Wright and M. L. Otte, "Wetland plant effects on the biogeochemistry of metals beyond the rhizosphere," Biology and Environment, vol. 99, no. 1, pp. 3-10, 1999.

[6] K. C. Sekhar, K. R. Supriya, C. T. Kamala, N. S. Chary, T. N. Rao, and Y. Anjaneyulu, "Speciation, accumulation of heavy metals in vegetation grown on sludge amended soils and their transfer to human food chain-a case study," Toxicological and Environmental Chemistry, vol. 82, no. 1-2, pp. 33-43, 2002.

[7] A. Shah, A. Niaz, N. Ullah et al., "Comparative study of heavy metals in soil and selected medicinal plants," Journal of Chemistry, vol. 2013, Article ID 621265, 5 pages, 2013.

[8] A. K. Ghosh, M. A. Bhatt, and H. P. Agrawal, "Effect of long-term application of treated sewage water on heavy metal accumulation in vegetables grown in Northern India," Environmental Monitoring and Assessment, vol. 184, no. 2, pp. 10251036, 2012.

[9] R. Milačič and J. Štupar, "Fractionation and oxidation of chromium in tannery waste-and sewage sludge-amended soils," Environmental Science and Technology, vol. 29, no. 2, pp. 506514, 1995.

[10] M. K. Banks, A. P. Schwab, and C. Henderson, "Leaching and reduction of chromium in soil as affected by soil organic content and plants," Chemosphere, vol. 62, no. 2, pp. 255-264, 2006.

[11] H. Chen and T. J. Cutright, "Preliminary evaluation of microbially mediated precipitation of cadmium, chromium, and nickel by Rhizosphere consortium," Journal of Environmental Engineering, vol. 129, no. 1, pp. 4-9, 2003.

[12] A. S. Chamon, M. H. Gerzabek, M. N. Mondol, S. M. Ullah, M. Rahman, and W. E. H. Blum, "Influence of cereal varieties and site conditions on heavy metal accumulations in cereal crops on polluted soils of Bangladesh," Communications in Soil Science and Plant Analysis, vol. 36, no. 7-8, pp. 889-906, 2005.

[13] H. Yao, J. Lu, X. Yuan et al., "Concentrations, bioavailability, and spatial distribution of soil heavy metals in a long-term wastewater irrigation area in North China," Clean-Soil, Air, Water, vol. 42, no. 3, pp. 331-338, 2014.

[14] T. Sato, S. Yamamoto, and M. Qadir, "Long-term effects of wastewater irrigation on soil heavy metal contamination in Peri -urban areas of Aleppo, Syria," International Journal of Agriculture and Biology, vol. 16, no. 6, pp. 1153-1158, 2014.

[15] J. Ingwersen and T. Streck, "Modeling the environmental fate of cadmium in a large wastewater irrigation area," Journal of Environmental Quality, vol. 35, no. 5, pp. 1702-1714, 2006.

[16] P. Li, X. Wang, G. Allinson, X. Li, and X. Xiong, "Risk assessment of heavy metals in soil previously irrigated with industrial wastewater in Shenyang, China," Journal of Hazardous Materials, vol. 161, no. 1, pp. 516-521, 2009. 
[17] J. Xu, L. Wu, A. C. Chang, and Y. Zhang, "Impact of longterm reclaimed wastewater irrigation on agricultural soils: a preliminary assessment," Journal of Hazardous Materials, vol. 183, no. 1-3, pp. 780-786, 2010.

[18] S.-A. Zheng, X. Zheng, T. Zhang, S. Liu, and X. Li, "Distribution and fractionation of heavy metals in soil profiles irrigated with wastewater for different periods of time," Fresenius Environmental Bulletin, vol. 21, no. 10, pp. 2881-2890, 2012.

[19] F. Ben Fredj, A. Wali, M. Khadhraoui et al., "Risk assessment of heavy metal toxicity of soil irrigated with treated wastewater using heat shock proteins stress responses: case of El Hajeb, Sfax, Tunisia," Environmental Science and Pollution Research, vol. 21, no. 6, pp. 4716-4726, 2014.

[20] S. Khan, Q. Cao, B.-D. Chen, and Y.-G. Zhu, "Humic acids increase the phytoavailability of $\mathrm{Cd}$ and $\mathrm{Pb}$ to wheat plants cultivated in freshly spiked, contaminated soil," Journal of Soils and Sediments, vol. 6, no. 4, pp. 236-242, 2006.

[21] B. Y. Chung, C. H. Song, B. J. Park, and J. Y. Cho, "Heavy metals in brown rice (Oryza sativa L.) and soil after longterm irrigation of wastewater discharged from domestic sewage treatment plants," Pedosphere, vol. 21, no. 5, pp. 621-627, 2011.

[22] G. Keser, "Effects of irrigation with wastewater on the physiological properties and heavy metal content in Lepidium sativum L. and Eruca sativa (Mill.)," Environmental Monitoring and Assessment, vol. 185, no. 7, pp. 6209-6217, 2013.

[23] S. Ogiyama, K. Sakamoto, H. Suzuki, S. Ushio, T. Anzai, and K. Inubushi, "Accumulation of zinc and copper in an arable field after animal manure application," Soil Science and Plant Nutrition, vol. 51, no. 6, pp. 801-808, 2005.

[24] Y. Zhao, Z. Yan, J. Qin, and Z. Xiao, "Effects of long-term cattle manure application on soil properties and soil heavy metals in corn seed production in Northwest China," Environmental Science and Pollution Research, vol. 21, no. 12, pp. 7586-7595, 2014.

[25] J. W. Huang and S. D. Cunningham, "Lead phytoextraction: Species variation in lead uptake and translocation," New Phytologist, vol. 134, no. 1, pp. 75-84, 1996.

[26] M. J. Salazar and M. L. Pignata, "Lead accumulation in plants grown in polluted soils. Screening of native species for phytoremediation," Journal of Geochemical Exploration, vol. 137, pp. 2936, 2014.

[27] S. Khan, Q. Cao, Y. M. Zheng, Y. Z. Huang, and Y. G. Zhu, "Health risks of heavy metals in contaminated soils and food crops irrigated with wastewater in Beijing, China," Environmental Pollution, vol. 152, no. 3, pp. 686-692, 2008.

[28] A. H. Bu-Olayan and B. V. Thomas, "Translocation and bioaccumulation of trace metals in desert plants of Kuwait governorates," Research Journal of Environmental Sciences, vol. 3, no. 5, pp. 581-587, 2009.

[29] M. Ackah, A. K. Anim, E. T. Gyamfi et al., "Uptake of heavy metals by some edible vegetables irrigated using wastewater: a preliminary study in Accra, Ghana," Environmental Monitoring and Assessment, vol. 186, no. 1, pp. 621-634, 2014.

[30] W. Yang, H. Li, T. Zhang, L. Sen, and W. Ni, "Classification and identification of metal-accumulating plant species by cluster analysis," Environmental Science and Pollution Research, vol. 21, no. 18, pp. 10626-10637, 2014.
[31] R. G. D. Steel and J. H. Torrie, Principles and Procedures of Statistics: A Biometric Approach, McGraw-Hill Publication, New York, NY, USA, 1980.

[32] M. J. Blaylock, D. E. Salt, S. Dushenkov et al., "Enhanced accumulation of $\mathrm{Pb}$ in Indian mustard by soil-applied chelating agents," Environmental Science and Technology, vol. 31, no. 3, pp. 860-865, 1997.

[33] H. Palacios, I. Iribarren, M. J. Olalla, and V. Cala, "Lead poisoning of horses in the vicinity of a battery recycling plant," Science of the Total Environment, vol. 290, no. 1-3, pp. 81-89, 2002.

[34] C. Chen, D. Huang, and J. Liu, "Functions and toxicity of nickel in plants: recent advances and future prospects," Clean-Soil, Air, Water, vol. 37, no. 4-5, pp. 304-313, 2009.

[35] M. Yusuf, Q. Fariduddin, S. Hayat, and A. Ahmad, "Nickel: an overview of uptake, essentiality and toxicity in plants," Bulletin of Environmental Contamination and Toxicology, vol. 86, no. 1, pp. 1-17, 2011.

[36] S. Fendorf, M. J. La Force, and G. Li, “Temporal changes in soil partitioning and bioaccessibility of arsenic, chromium, and lead," Journal of Environmental Quality, vol. 33, no. 6, pp. 20492055, 2004.

[37] P. M. Outridge and B. N. Noller, "Accumulation of toxic trace elements by freshwater vascular plants," Reviews of Environmental Contamination and Toxicology, vol. 121, pp. 1-63, 1991.

[38] P. C. Srivastava and U. C. Gupta, Trace Elements in Crop Production, Science Publishing, Lebanon, UK, 1996.

[39] M. N. Jiménez, G. Bacchetta, M. Casti, F. B. Navarro, A. M. Lallena, and E. Fernández-Ondoño, "Study of $\mathrm{Zn}, \mathrm{Cu}$ and $\mathrm{Pb}$ content in plants and contaminated soils in Sardinia," Plant Biosystems, vol. 148, no. 3, pp. 419-428, 2014.

[40] M. S. Li, Y. P. Luo, and Z. Y. Su, "Heavy metal concentrations in soils and plant accumulation in a restored manganese mineland in Guangxi, South China," Environmental Pollution, vol. 147, no. 1, pp. 168-175, 2007.

[41] A. Thapliyal, P. Vasudevan, M. G. Dastidar, M. Tandon, and S. Mishra, "Effects of irrigation with domestic wastewater on productivity of green chili and soil status," Communications in Soil Science and Plant Analysis, vol. 44, no. 15, pp. 2327-2343, 2013.

[42] A.-I. Smical, V. Hotea, V. Oros, J. Juhasz, and E. Pop, "Studies on transfer and bioaccumulation of heavy metals from soil into lettuce," Environmental Engineering and Management Journal, vol. 7, no. 5, pp. 609-615, 2008.

[43] N. Rascio and F. Navari-Izzo, "Heavy metal hyperaccumulating plants: how and why do they do it? And what makes them so interesting?" Plant Science, vol. 180, no. 2, pp. 169-181, 2011.

[44] Z. Chen, Y. Ai, C. Fang et al., "Distribution and phytoavailability of heavy metal chemical fractions in artificial soil on rock cut slopes alongside railways," Journal of Hazardous Materials, vol. 273, pp. 165-173, 2014.

[45] M. Wahsha, C. Bini, E. Argese, F. Minello, S. Fontana, and H. Wahsheh, "Heavy metals accumulation in willows growing on Spolic Technosols from the abandoned Imperina Valley mine in Italy," Journal of Geochemical Exploration, vol. 123, pp. 19-24, 2012.

[46] H. Avci and T. Deveci, "Assessment of trace element concentrations in soil and plants from cropland irrigated with 
wastewater," Ecotoxicology and Environmental Safety, vol. 98, pp. 283-291, 2013.

[47] K. K. Tiwari, N. K. Singh, M. P. Patel, M. R. Tiwari, and U. N. Rai, "Metal contamination of soil and translocation in vegetables growing under industrial wastewater irrigated agricultural field of Vadodara, Gujarat, India," Ecotoxicology and Environmental Safety, vol. 74, no. 6, pp. 1670-1677, 2011.

[48] R. S. Pawan, S. Pratima, S. T. Chirika, and K. B. Pradeep, "Studies and determination of heavy metals in waste tyres and their impacts on the environment," Pak Journal of Analytical Environment Chemistry, vol. 7, no. 2, pp. 70-76, 2006. 

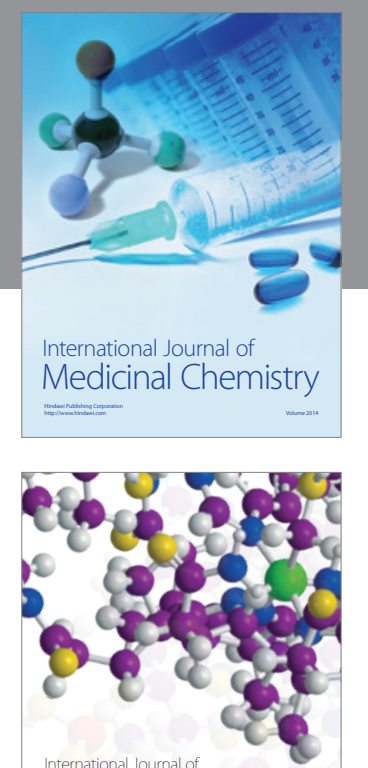

\section{Carbohydrate} Chemistry

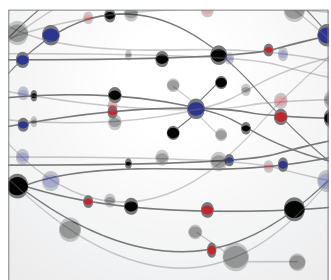

The Scientific World Journal
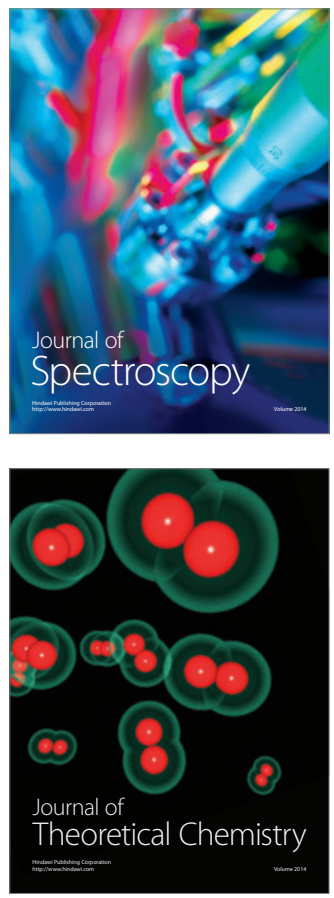
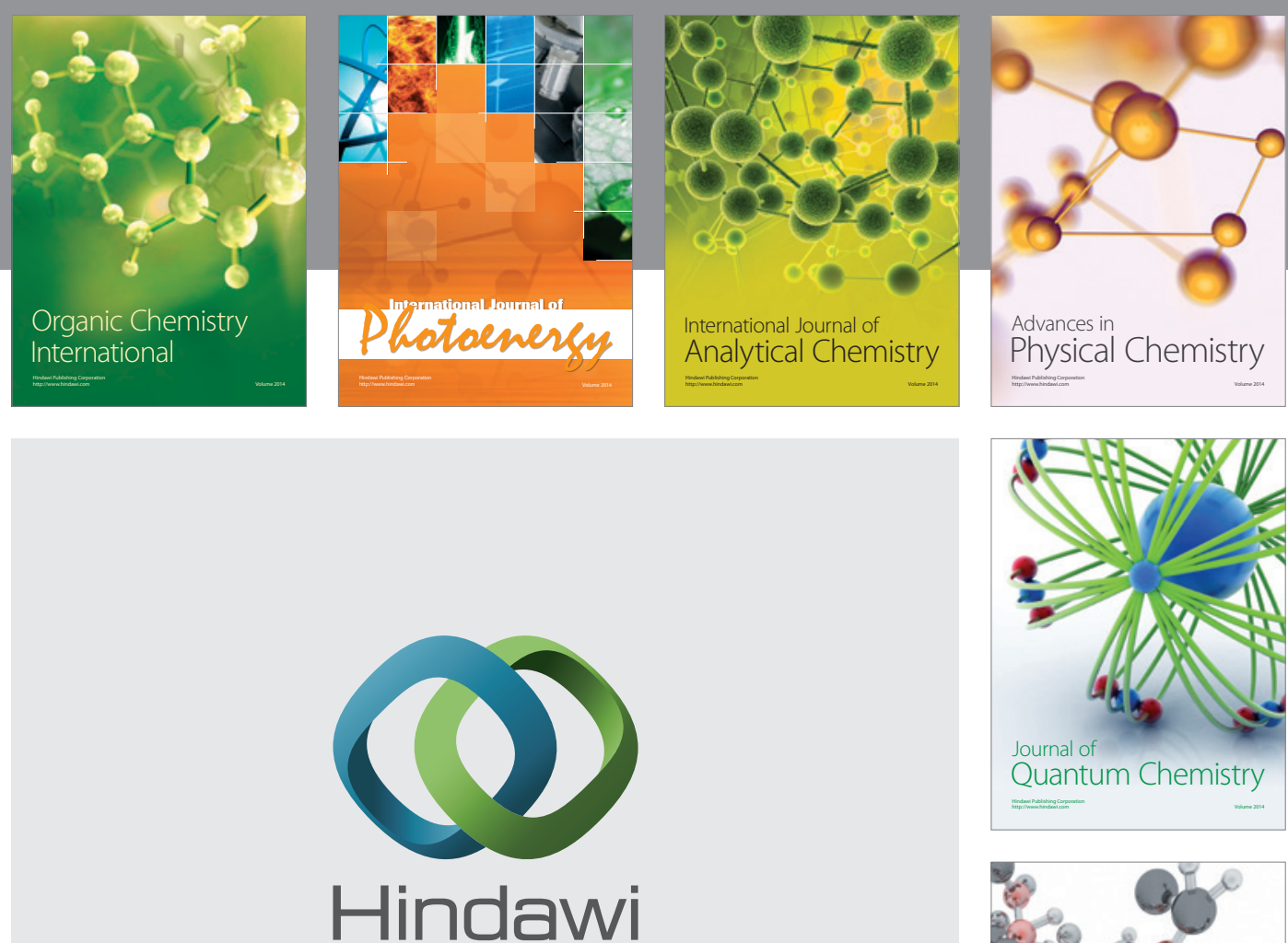

Submit your manuscripts at

http://www.hindawi.com

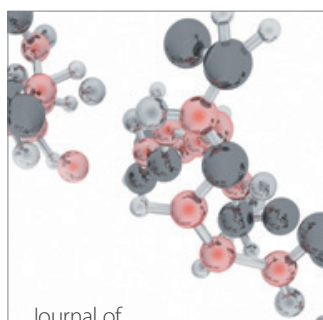

Analytical Methods

in Chemistry

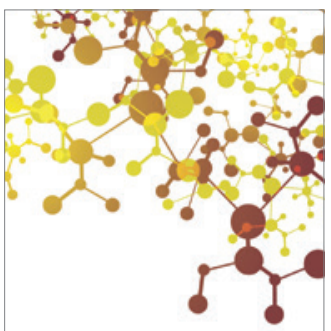

Journal of

Applied Chemistry

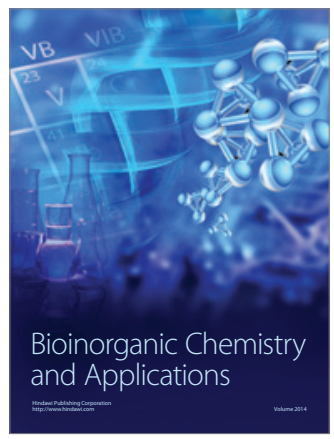

Inorganic Chemistry
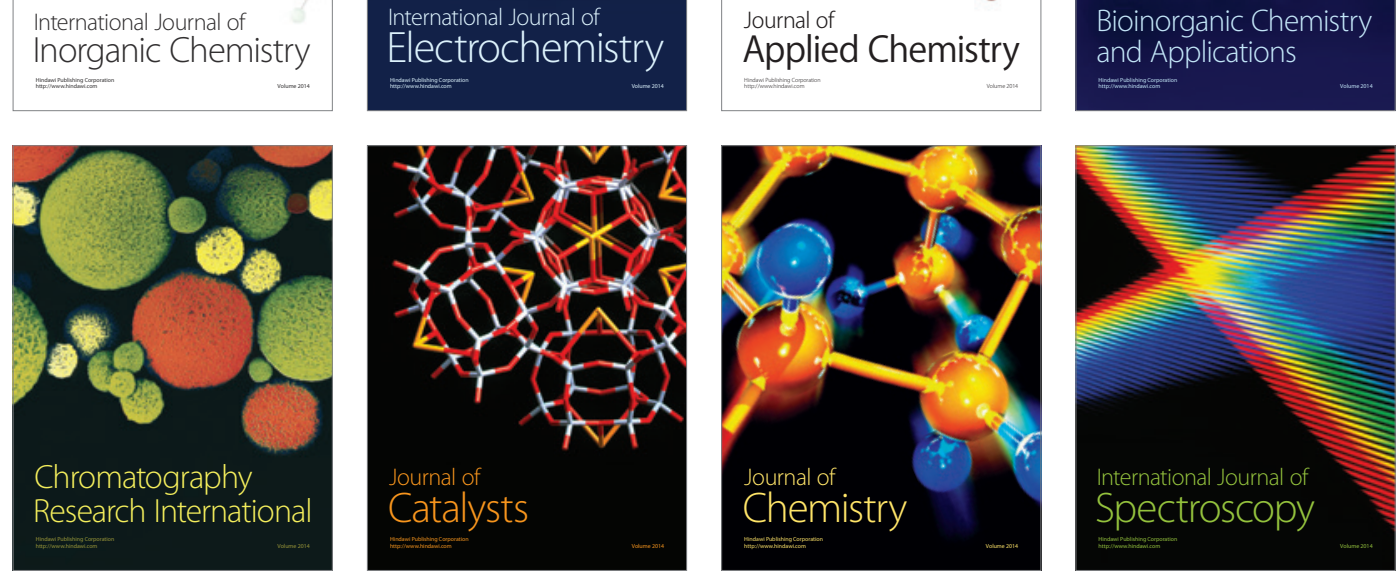